\title{
DESIGN AND ANALYSIS OF COMPOSITE DRIVE SHAFT
}

\author{
V. S. BHAJANTRI ${ }^{1}$, S. C. BAJANTRI ${ }^{2}$, A. M. SHINDOLKAR ${ }^{3}$, S. S. AMARAPURE ${ }^{4}$ \\ ${ }^{1}$ Assistant Professor, Dept. Of Mech. Engg., SCET, Belgaum-591156 \\ ${ }^{2}$ Assistant Professor, Dept. Of Mech. Engg., SCET, Belgaum-591156 \\ ${ }^{3}$ Assistant Professor, Dept. Of Mech. Engg., SCET, Belgaum-591156 \\ ${ }^{4}$ Assistant Professor, Dept. Of Mech. Engg., SCET, Belgaum-591156
}

\begin{abstract}
Substituting composite structures for conventional metallic structures has much advantage because of higher specific stiffness and strength of composite materials. This work deals with replacement of conventional two piece steel drive shaft with a single-piece eglass/epoxy, high strength carbon/epoxy and high modulus carbon/epoxy composite drive shaft for automobile shaft for an automotive application. The design parameters were optimized with the objective on minimizing the weight of composite drive shaft.
\end{abstract}

$* * *$

\section{INTRODUCTION}

Composite materials have been widely used to improve the performance of various types of structures. Compared to conventional materials, the main advantages of composites are their superior stiffness to mass ratio as well as high strength to weight ratio. Because of these advantages, composites have been increasingly incorporated in structural components in various industrial fields. Some examples are helicopter rotor blades, aircraft wings in aerospace engineering, and bridge structures in civil engineering applications. Some of the basic concepts of composite materials are discussed in the following section to better acquaint ourselves with the behaviour of composites.

\subsection{Basic Concepts of Composite Materials}

Composite materials are basically hybrid materials formed of multiple materials in order to utilize their individual structural advantages in a single structural material. The constituents are combined at a macroscopic level and are not soluble in each other. The key is the macroscopic examination of a material wherein the components can be identified by the naked eye. Different materials can be combined on a microscopic scale, such as in alloying of metals, but the resulting material is, for all practical purposes, macroscopically homogeneous, i.e. the components cannot be distinguished by the naked eye and essentially acts together. The advantage of composite materials is that, if well designed, they usually exhibit the best qualities of their components or constituents and often some qualities that neither constituent possesses. Some of the properties that can be improved by forming a composite material are strength, fatigue life, stiffness, temperature-dependent behaviour, corrosion resistance, thermal insulation, wear resistance, thermal conductivity, attractiveness, acoustical insulation and weight. Naturally, not all of these properties are improved at the same time nor is there usually any requirement to do so. In fact, some of the properties are in conflict with one another, e.g., thermal insulation versus thermal conductivity. The objective is merely to create a material that has only the characteristics needed to perform the designed task.

There are two building blocks that constitute the structure of composite materials. One constituent is called the reinforcing phase and the one in which it is embedded is called the matrix. The reinforcing phase material may be in the form of fibres, particulates, flakes. The matrix phase materials are generally continuous. Examples of composite systems include concrete reinforced with steel, epoxy reinforced with graphite fibres, etc

\subsection{Fibres}

Fibres are the principal constituent in a fibre-reinforced composite material. They occupy the largest volume fraction in a composite laminate and share the major portion of the load acting on a composite structure. Proper selection of the type, amount and orientation of fibres is very important, because it influences the following characteristics of a composite laminate.

a. Specific gravity

b. Tensile strength and modulus

c. Compressive strength and modulus

d. Fatigue strength and fatigue failure mechanisms

e. Electric and thermal conductivities

f. Cost

The various types of fibres currently in use are
a. Glass Fibres
b. Carbon Fibres
c. Aramid Fibres
d. Boron Fibres
e. Silicon Carbide Fibres

\subsection{Matrix}

In a composite material the fibres are surrounded by a thin layer of matrix material that holds the fibres permanently in the desired 
orientation and distributes an applied load among all the fibres. The matrix also plays a strong role in determining the environmental stability of the composite article as well as mechanical factors such as toughness and shear strength.

The matrix binds the fibres together, holding them aligned in the important stressed directions. The matrix must also isolate the fibres from each other so that they can act as separate entities. The matrix should protect the reinforcing filaments from mechanical damage (e.g. abrasion) and from environmental attack. A ductile matrix will provide a means of slowing down or stopping cracks that might have originated at broken fibres; conversely, a brittle matrix may depend upon the fibres to act as matrix crack stoppers. Through the quality of its "grip" on the fibres (the interfacial bond strength), the matrix can also be an important means of increasing the toughness of the composite.

Because the reinforcing fibres can be oriented during fabrication of item, composites can be tailored to meet increased load demands in specific directions. The combined fibre-matrix system is an engineered material designed to maximize mechanical and environmental performance.

\subsection{Classification of Composites}

Composite materials in general are categorised based on the kind of reinforcements or the surrounding matrix. There are four commonly accepted types of composite materials based on reinforcements-

a. Fibrous composite materials that consist of fibres in a matrix.

b. Laminated composite materials that consist of layers of various materials.

c. Particulate composite materials that are composed of particles in a matrix.

d. Combinations of some or all of the first three types.

And the major composite classes based on structural composition of the matrix are-
a. Polymer-Matrix Composites
b. Metal- Matrix Composites
c. Ceramic- Matrix Composites
d. Carbon- Carbon Composites
e. Hybrid Composites

\subsection{Applications of Composite Materials}

The common applications of composites are extending day by day. Nowadays they are used in medical applications too. Some other fields of applications are,

- Automotive : Drive shafts, clutch plates, fibre Glass/Epoxy leaf springs for heavy trucks and trailers, rocker arm covers, suspension arms and bearings for steering system, bumpers, body panels and doors.

- Aerospace: Drive shafts, rudders, elevators, bearings, landing gear doors, panels and floorings of airplanes, payload bay doors, remote manipulator arm, high gain antenna, antenna ribs and struts etc.

- Marine: Propeller vanes, fans \& blowers, gear cases, valves \&strainers, condenser shells.

- Chemical Industries: Composite vessels for liquid natural gas for alternative fuel vehicle, racked bottles for fire service, mountain climbing, underground storage tanks, ducts and stacks etc.

- Electrical \& Electronics: Structures for overhead transmission lines for railways, Power line insulators, Lighting poles, Fibre optics tensile members etc.

\subsection{Drive Shaft}

As mentioned above, recent developments in the applications of composite materials have shown that a composite material structural member used in power transmission can be of a great assistance in overcoming a few of the problems faced with conventional drive shafts. The assessment of the extent of this fact is the essence of this work. Therefore a good understanding of the drive shaft would be a prerequisite and is discussed in the following section.

A drive shaft, propeller shaft (prop shaft), or Cardan shaft is a mechanical component for transmitting torque and rotation, usually used to connect other components of a drive train that cannot be connected directly because of distance or the need to allow for relative movement between them. Drive shafts are carriers of torque. They are subject to torsion and shear stress, equivalent to the difference between the input torque and the load. They must therefore be strong enough to bear the stress, whilst avoiding too much additional weight as that would in turn increase their inertia. Therefore a drive shaft is expected to function, as follows.

a. It must transmit torque from the transmission to the differential gear box.

b. The drive shaft must also be capable of rotating at very high speeds as required by the vehicle.

c. The drive shaft must also operate through constantly changing angles between the transmission, the differential and the axels.

d. The length of the drive shaft must also be capable of changing while transmitting torque.

Thus the design of a drive shaft presents itself as a case of torsion problem. Further, with regard to the conventional drive shafts following shortcomings were observed some of which could be addressed better with a composite shaft.

1. They have less specific modulus and strength

2. Increased weight

3. Conventional steel drive shafts are usually manufactured in two pieces to increase the fundamental bending natural frequency because the bending natural frequency of a shaft is inversely proportional to the square of beam length and proportional to the square root of specific modulus. 
Therefore the steel drive shaft is made in two sections connected by a support structure, bearings and Ujoints and hence overall weight of assembly will be more.

4. Its corrosion resistance is less as compared with composite materials.

5. Steel drive shafts have less damping capacity.

Since a drive shaft is a case of torsion problem an understanding of the methodology of solving such a problem in structural mechanics is necessary.

\subsection{Torsion Problem in Structural Mechanics}

Torsion of cylindrical shafts has long been a subject of interest in power transmission problems. To this end the stiffness of a cylindrical shaft under torsional loading is considered. The axial displacement field of the cross-section is assumed not to vary along the axial direction away from the ends of the shaft. Under this assumption, the torsional rigidity is only dependent on the shape of the cross-section. The governing equations of this boundary value problem can be formulated in terms of a Laplace or Poisson Equation. Within the former one, one uses the warping function as dependent variable, while in the latter the Prandtl's stress function is used. The solutions for the warping and Prandtl's stress function have been obtained exactly for simple cross-sectional shapes such as a circle, annulus, ellipse, rectangle, and triangle. For more complicated shapes, numerical methods are usually employed, such as, the finite difference method, finite element method and boundary element method. Some authors use the approach of combination of experimental and analytical methods to predict the effective in-plane and outof-plane shear moduli of structural composite laminates. Due to the extensive use of composite materials, the study of compound bars under torsion has become a point of focus in the recent days.

\subsection{Torsion of Composite Shafts}

Compared to homogeneous cylindrical shafts, the torsional behaviour of composite shafts is considerably more complicated. The torsional rigidity not only depends on the global crosssectional geometry, but also on the properties and configurations of each constituent. The analytical solution of compound bars under torsion was first obtained by Muskhelishvili (1963), where the solution was expressed in terms of eigen functions. Packhamand Shail (1978) used linear combinations of solutions of a homogeneous shaft to solve the problem in which the cross section is symmetric with respect to the common boundary. The elastic properties of non-homogeneous anisotropic beams are usually of engineering interest. Torsional rigidities of multilayered composite beams are especially needed when structures are under torsional loading. Savoia and Tullini (1993) analyzed the torsional response of composite beams of arbitrary cross section. The boundary value problem was formulated in terms of both warping and Prandtl's stress function. Using the eigen function expansion method, the exact solution of rectangular multilayered orthotropic beams under uniform torsion was derived. Swanson (1998) extended the existing solutions of torsion of orthotropic laminated rectangular beams to the high aspect ratio case. Based on the membrane analogy, an approximate solution of general, thin, laminated, open cross sections was derived.

In this study, an analytical approach is proposed to solve the torsion problem of laminated composite shafts that consist of orthotropic sublaminates. The present approach uses the concept of elastic constants (Chou, et al., 1972), in which the threedimensional nonhomogeneous orthotropic laminate is replaced by an equivalent homogeneous orthotropic material. A small element consisting of $\mathrm{n}$ layers from the composite material, [assumed to represent the behaviour of the overall composite laminate] is considered to be under a uniform state of stress when the composite laminate is under arbitrary loading. Two assumptions have been made in this regard: first, the normal strains and shear strains parallel to the plane of layers are uniform and the same for each constituent and the corresponding stresses are averaged. Second, the normal stresses and shear stresses perpendicular to the plane of layers are uniform and equal for each constituent and the corresponding strains are averaged. Under these two assumptions, the equilibrium at each sublaminate interface and compatibility conditions of materials are satisfied automatically. As the thickness of each layer approaches zero, the overall effective elastic constants are developed. The effective shear moduli of the composite laminates are used to calculate the overall torsional rigidity of the orthotropic laminated shaft.

Having convinced ourselves about the nature of the problem and the possible solution to it, we now move on to develop a better understanding of the fundamentals necessary for the present work. A qualitative literature survey would greatly help us achieve it and is presented in the following chapter.

\subsection{Analysis of Composite Drive Shaft}

A good design solution can be delivered only when the function of the component being designed, is known before hand with proper working condition specifications. Ability of different methodologies in solving for these conditions can be appreciated based on the complexity of the problem, though. Presently, the specifications of the composite shaft to be designed are considered to be same as that of an optimally designed steel shaft. Comparison is made between the composite and the conventional steel shaft for maximum shear stress induced in the shafts and maximum deflections in the shafts. Finally modal analysis is carried out to study the variation in natural frequency by changing the fibre angle orientation of different layer of the composite shaft.

\subsubsection{Specification of Composite Shaft}

In the present analysis hollow composite shaft is modelled in ANSYS by using shell element and having following specifications- 
a) Length of shaft $\mathrm{L}=1 \mathrm{~m}$

b) Outer radius of the shaft $\mathrm{R}_{\mathrm{o}}=50 \mathrm{~mm}$ with $5 \mathrm{~mm}$ thickness.

c) Torque applied at free end of shaft $T_{\max }=3000 \mathrm{~N}-\mathrm{m}$

\subsubsection{Assumptions}

In the analysis of the composite drive shaft following assumptions are made.

1. The shaft rotates at a constant speed about its longitudinal axis.

2. The shaft has a uniform, circular cross section.

3. The shaft is perfectly balanced, i.e., at every cross section, the mass centre coincides with the geometric centre.

4. All damping and nonlinear effects are excluded.

5. The stresses-strain relationship for composite material is linear and elastic, i.e., Hooke's law is applicable for composite materials.

6. Acoustical fluid interactions are neglected, i.e., the shaft is assumed to be acting in a vacuum.

7. Since lamina is thin and no out-of-plane loads are applied, it is considered to be in plane stress condition.

\subsubsection{Selection of Cross-Section}

The shaft can be solid circular or hollow circular. Here hollow circular cross-section was chosen because:

i. The hollow circular shafts are stronger in per kg weight than solid circular shafts.

ii. The stress distribution in case of solid shaft is zero at the centre and maximum at the outer surface while in hollow shaft stress variation is smaller. In solid shafts the material close to the centre are not fully utilized.

\subsubsection{Selection of Reinforcement Fibre}

Fibres are available with widely differing properties. Review of the design and performance requirements usually dictate the fibre to be used. So in our analysis we will consider the Carbon fibres because its advantages include high specific strength and modulus, low coefficient of thermal expansion, and high fatigue strength which is ideal fibre for torque transmitting shaft.

\subsubsection{Selection of Resin System}

The important considerations in selecting resin are cost, temperature capability, elongation to failure and resistance to impact (a function of modulus of elongation). The resins selected for most of the drive shafts are either epoxies or vinyl esters. Here, epoxy resin was selected due to its high strength, good wetting of fibres, lower curing shrinkage, and better dimensional stability.

\subsubsection{Why Carbon Epoxy Composite?}

Following are the features of carbon epoxy composite, the reason for which it is chosen.

1. Carbon epoxy composite gives high tensile strength, high modulus of rigidity as compared to other composites.

2. Carbon epoxy composite has unique damping characteristic.

3. Carbon epoxy composite has positive coefficient of thermal expansion i.e. tensile strength of this composite increases with temperature.

4. Carbon epoxy composite is fatigue, wear and corrosion resistant.

\subsubsection{Selection of Material}

Based on the advantages discussed above, the high strength and high modulus Carbon/Epoxy materials are selected for composite drive shaft. The Table 5.1 shows the properties of the Carbon/Epoxy material used for composite drive shaft.

\subsubsection{Modal Analysis of Composite Shaft}

Modal analysis is used to determine the vibration characteristics such as natural frequencies and mode shapes of a structure or a machine component while it is being designed. A modal analysis can be performed using the ANSYS. The vibration problem is described by a set of equations, and there is a natural vibration mode for every equation that can be extracted by using an Eigen value extraction analysis. The displacement behaviour dominating any structure subject to vibration is global; therefore, modal analysis is utilized in these types of problems. In modal analysis, the model of the composite shaft does not need a fine mesh because the stress output is not required.

Additionally, there is no requirement to input an applied load, because the natural frequency is only a function of mass and stiffness. The ends of the composite shaft model were modelled as simply-supported, and the boundary condition was varied until the value of the natural frequency became nearly coincident with that presented by a reliable example. It was recognized that the end support conditions must also be applied to the edges of the composite shaft. The rotational speed is limited by lateral stability considerations. Most designs are sub critical, i.e. rotational speed must be lower than the first natural bending frequency of the shaft. The natural frequency depends on the diameter of the shaft, thickness of the hollow shaft, specific stiffness and the length. Boundary conditions for the modal analysis are shown in Fig 5.3 below 


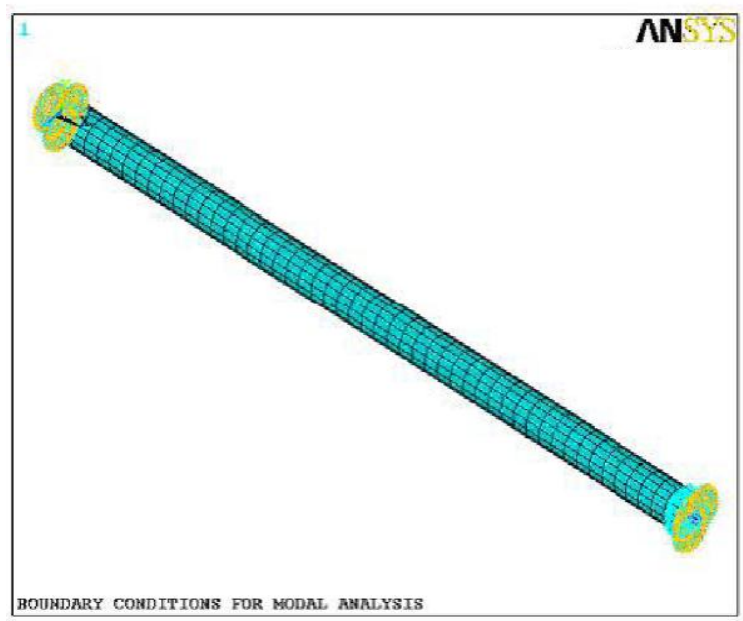

Fig. 1 Boundary conditions for the modal analysis for composite shaft

\subsubsection{Modelling of Conventional Steel Shaft}

Conventional drive shaft is made up of steel for most of the automobile, but sometimes aluminium is also used. To compare the capability of composite material, steel shaft strength is compared with composite.

In present analysis conventional shaft is modelled in ANSYS and its length is considered as $1 \mathrm{~m}$ and diameter of the shaft as 50 $\mathrm{mm}$ with $2.032 \mathrm{~mm}$ thickness. Similar dimensions are used in composite shaft analysis. Steel material has young's modulus of $\mathrm{Ex}=210 \mathrm{GPa}$ and Poisson ratio equal to 0.3. Comparison is carried out based on maximum deformation, maximum stresses induced in the shaft. Table 5.2 below shows the properties of steel.

Table 2 Properties of steel

\begin{tabular}{|l|}
\hline Steel \\
\hline $\mathrm{E}=207$ e $9 \mathrm{~N} / \mathrm{m} 2$ \\
\hline$\mu=0.3$ \\
\hline $\mathrm{G}=80$ e $9 \mathrm{~N} / \mathrm{m} 2$ \\
\hline Density $=7600 \mathrm{Kg} / \mathrm{m} 3$ \\
\hline Max. Torque Tmax $=3000 \mathrm{~N}-\mathrm{m}$ \\
\hline
\end{tabular}

Now for the steel shaft the maximum stresses and maximum deflections are found out first and then modal analysis is done. Analysis procedure for steel shaft is the same as that for composite shaft. The only exception being the homogeneous, isotropic nature input, meaning the same value input for all directions.
In the chapter that follows are presented the discussions about the results obtained from the above analysis, for various orientations and different layers of the composite shaft and for the steel shaft.

\section{RESULTS AND DISCUSSIONS}

\subsection{Static Analysis}

The maximum shear stress and maximum deflection for each layer are obtained using ANSYS by varying the orientation of fibre in that layer by $10^{\circ}$ and keeping the orientation of other layers constant i.e. $0^{0}$.

\subsection{Variation of Stresses with Fibre Angle Orientation}

\section{of Different Layers}

\subsubsection{Layer 1}

Table 3 Variations in stresses by changing fibre angle orientation of layer 1

\begin{tabular}{|l|l|l|l|l|}
\hline Configuration & Layer 1 & Layer 2 & Layer 3 & Layer 4 \\
\hline $10 / 0 / 0 / 0$ & $4.79 \mathrm{E}+06$ & $2.98 \mathrm{E}+06$ & $6.49 \mathrm{E}+06$ & $3.25 \mathrm{E}+06$ \\
\hline $20 / 0 / 0 / 0$ & $7.39 \mathrm{E}+06$ & $2.86 \mathrm{E}+06$ & $6.29 \mathrm{E}+06$ & $3.20 \mathrm{E}+06$ \\
\hline $30 / 0 / 0 / 0$ & $9.18 \mathrm{E}+06$ & $2.74 \mathrm{E}+06$ & $6.07 \mathrm{E}+06$ & $3.16 \mathrm{E}+06$ \\
\hline $40 / 0 / 0 / 0$ & $9.84 \mathrm{E}+06$ & $2.68 \mathrm{E}+06$ & $6.00 \mathrm{E}+06$ & $3.13 \mathrm{E}+06$ \\
\hline $50 / 0 / 0 / 0$ & $9.42 \mathrm{E}+06$ & $2.71 \mathrm{E}+06$ & $6.08 \mathrm{E}+06$ & $3.19 \mathrm{E}+06$ \\
\hline $60 / 0 / 0 / 0$ & $8.11 \mathrm{E}+06$ & $2.80 \mathrm{E}+06$ & $6.24 \mathrm{E}+06$ & $3.23 \mathrm{E}+06$ \\
\hline $70 / 0 / 0 / 0$ & $6.20 \mathrm{E}+06$ & $2.91 \mathrm{E}+06$ & $6.41 \mathrm{E}+06$ & $3.26 \mathrm{E}+06$ \\
\hline $80 / 0 / 0 / 0$ & $4.13 \mathrm{E}+06$ & $2.99 \mathrm{E}+06$ & $6.54 \mathrm{E}+06$ & $3.27 \mathrm{E}+06$ \\
\hline $90 / 0 / 0 / 0$ & $3.01 \mathrm{E}+06$ & $3.02 \mathrm{E}+06$ & $6.58 \mathrm{E}+06$ & $3.28 \mathrm{E}+06$ \\
\hline
\end{tabular}
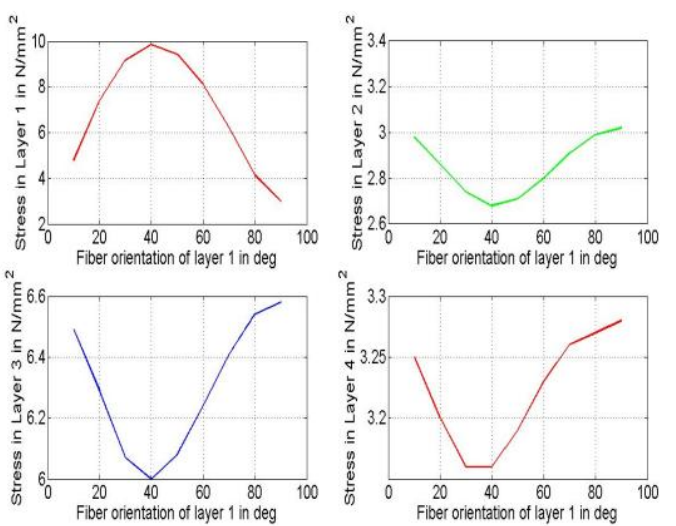

Fig 2 Variations in stresses by changing fibre angle orientation of layer 1 


\subsubsection{Layer 2}

Table 4 Variations in stresses by changing fibre angle orientation of layer

\begin{tabular}{|l|l|l|l|l|}
\hline Configuration & Layer1 & Layer2 & Layer3 & Layer4 \\
\hline $0 / 10 / 0 / 0$ & $2.97 \mathrm{E}+06$ & $4.80 \mathrm{E}+06$ & $6.48 \mathrm{E}+06$ & $3.24 \mathrm{E}+06$ \\
\hline $0 / 20 / 0 / 0$ & $2.85 \mathrm{E}+06$ & $7.37 \mathrm{E}+06$ & $6.29 \mathrm{E}+06$ & $3.17 \mathrm{E}+06$ \\
\hline $0 / 30 / 0 / 0$ & $2.73 \mathrm{E}+06$ & $9.12 \mathrm{E}+06$ & $6.04 \mathrm{E}+06$ & $3.11 \mathrm{E}+06$ \\
\hline $0 / 40 / 0 / 0$ & $2.67 \mathrm{E}+06$ & $9.74 \mathrm{E}+06$ & $5.95 \mathrm{E}+06$ & $3.10 \mathrm{E}+06$ \\
\hline $0 / 50 / 0 / 0$ & $2.70 \mathrm{E}+06$ & $9.30 \mathrm{E}+06$ & $6.02 \mathrm{E}+06$ & $3.13 \mathrm{E}+06$ \\
\hline $0 / 60 / 0 / 0$ & $2.79 \mathrm{E}+06$ & $8.01 \mathrm{E}+06$ & $6.19 \mathrm{E}+06$ & $3.18 \mathrm{E}+06$ \\
\hline $0 / 70 / 0 / 0$ & $2.90 \mathrm{E}+06$ & $6.13 \mathrm{E}+06$ & $6.38 \mathrm{E}+06$ & $3.23 \mathrm{E}+06$ \\
\hline $0 / 80 / 0 / 0$ & $2.98 \mathrm{E}+06$ & $4.11 \mathrm{E}+06$ & $6.53 \mathrm{E}+06$ & $3.26 \mathrm{E}+06$ \\
\hline $0 / 90 / 0 / 0$ & $3.01 \mathrm{E}+06$ & $3.02 \mathrm{E}+06$ & $6.58 \mathrm{E}+06$ & $3.27 \mathrm{E}+06$ \\
\hline
\end{tabular}
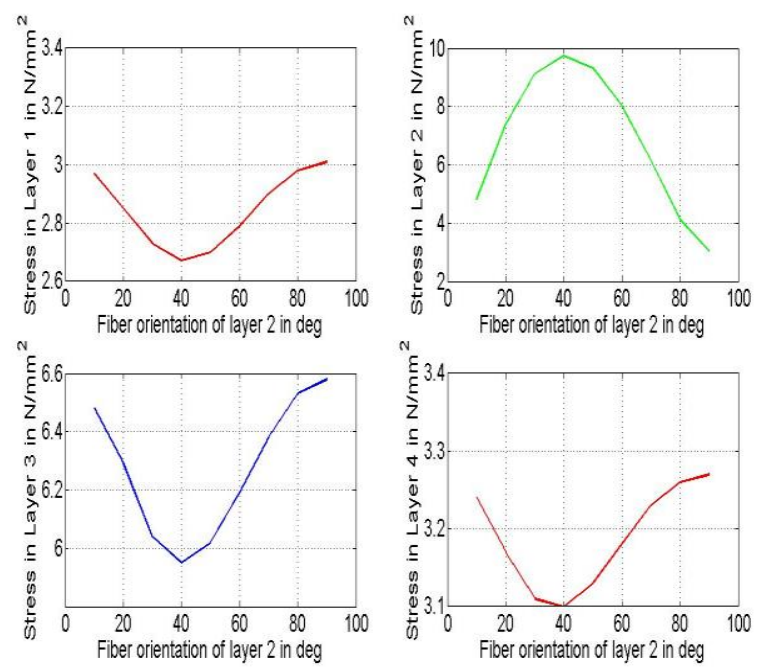

Fig 3 Variations in stresses by changing fibre angle orientation of layer 2

\subsubsection{Layer 3}

Table 5 Variations in stresses by changing fibre angle orientation of layer 3

\begin{tabular}{|l|l|l|l|l|}
\hline $\begin{array}{l}\text { Configurat } \\
\text { ion }\end{array}$ & deflection1 & $\begin{array}{l}\text { Deflection } \\
2\end{array}$ & Deflection3 & Deflection4 \\
\hline $10 / 0 / 0 / 0$ & $2.82 \mathrm{E}-04$ & $2.82 \mathrm{E}-04$ & $2.82 \mathrm{E}-04$ & $2.82 \mathrm{E}-04$ \\
\hline $20 / 0 / 0 / 0$ & $2.71 \mathrm{E}-04$ & $2.71 \mathrm{E}-04$ & $2.71 \mathrm{E}-04$ & $2.71 \mathrm{E}-04$ \\
\hline $30 / 0 / 0 / 0$ & $2.60 \mathrm{E}-04$ & $2.60 \mathrm{E}-04$ & $2.60 \mathrm{E}-04$ & $2.60 \mathrm{E}-04$ \\
\hline $40 / 0 / 0 / 0$ & $2.54 \mathrm{E}-04$ & $2.54 \mathrm{E}-04$ & $2.54 \mathrm{E}-04$ & $2.54 \mathrm{E}-04$ \\
\hline $50 / 0 / 0 / 0$ & $2.57 \mathrm{E}-04$ & $2.57 \mathrm{E}-04$ & $2.57 \mathrm{E}-04$ & $2.57 \mathrm{E}-04$ \\
\hline $60 / 0 / 0 / 0$ & $2.66 \mathrm{E}-04$ & $2.66 \mathrm{E}-04$ & $2.66 \mathrm{E}-04$ & $2.66 \mathrm{E}-04$ \\
\hline $70 / 0 / 0 / 0$ & $2.76 \mathrm{E}-04$ & $2.76 \mathrm{E}-04$ & $2.76 \mathrm{E}-04$ & $2.76 \mathrm{E}-04$ \\
\hline $80 / 0 / 0 / 0$ & $2.84 \mathrm{E}-04$ & $2.84 \mathrm{E}-04$ & $2.84 \mathrm{E}-04$ & $2.84 \mathrm{E}-04$ \\
\hline $90 / 0 / 0 / 0$ & $2.87 \mathrm{E}-04$ & $2.87 \mathrm{E}-04$ & $2.87 \mathrm{E}-04$ & $2.87 \mathrm{E}-04$ \\
\hline
\end{tabular}
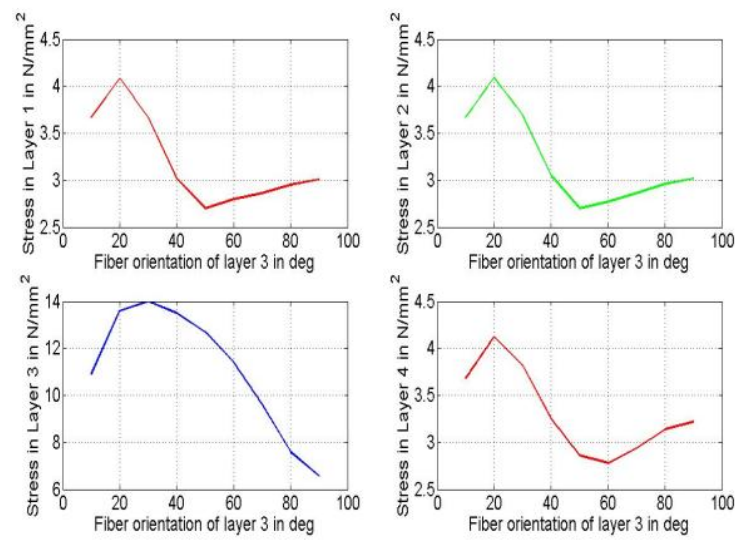

Fig 4 Variations in stresses by changing fibre angle orientation of layer 3

\subsubsection{Layer 4}

Table 6 Variations in stresses by changing fibre angle orientation of layer 4

\begin{tabular}{|l|l|l|l|l|}
\hline Configuration & LAYER1 & LAYER2 & LAYER3 & LAYER4 \\
\hline $0 / 0 / 0 / 10$ & $2.91 \mathrm{E}+06$ & $2.91 \mathrm{E}+06$ & $7.05 \mathrm{E}+06$ & $4.30 \mathrm{E}+06$ \\
\hline $0 / 0 / 0 / 20$ & $2.65 \mathrm{E}+06$ & $2.63 \mathrm{E}+06$ & $7.42 \mathrm{E}+06$ & $5.70 \mathrm{E}+06$ \\
\hline $0 / 0 / 0 / 30$ & $2.37 \mathrm{E}+06$ & $2.39 \mathrm{E}+06$ & $7.69 \mathrm{E}+06$ & $6.21 \mathrm{E}+06$ \\
\hline $0 / 0 / 0 / 40$ & $2.29 \mathrm{E}+06$ & $2.35 \mathrm{E}+06$ & $7.73 \mathrm{E}+06$ & $6.19 \mathrm{E}+06$ \\
\hline $0 / 0 / 0 / 50$ & $2.36 \mathrm{E}+06$ & $2.42 \mathrm{E}+06$ & $7.60 \mathrm{E}+06$ & $5.91 \mathrm{E}+06$ \\
\hline $0 / 0 / 0 / 60$ & $2.58 \mathrm{E}+06$ & $2.57 \mathrm{E}+06$ & $7.36 \mathrm{E}+06$ & $5.30 \mathrm{E}+06$ \\
\hline $0 / 0 / 0 / 70$ & $2.80 \mathrm{E}+06$ & $2.80 \mathrm{E}+06$ & $7.03 \mathrm{E}+06$ & $4.42 \mathrm{E}+06$ \\
\hline $0 / 0 / 0 / 80$ & $2.96 \mathrm{E}+06$ & $2.96 \mathrm{E}+06$ & $6.72 \mathrm{E}+06$ & $3.50 \mathrm{E}+06$ \\
\hline $0 / 0 / 0 / 90$ & $3.01 \mathrm{E}+06$ & $3.02 \mathrm{E}+06$ & $6.58 \mathrm{E}+06$ & $3.25 \mathrm{E}+06$ \\
\hline
\end{tabular}



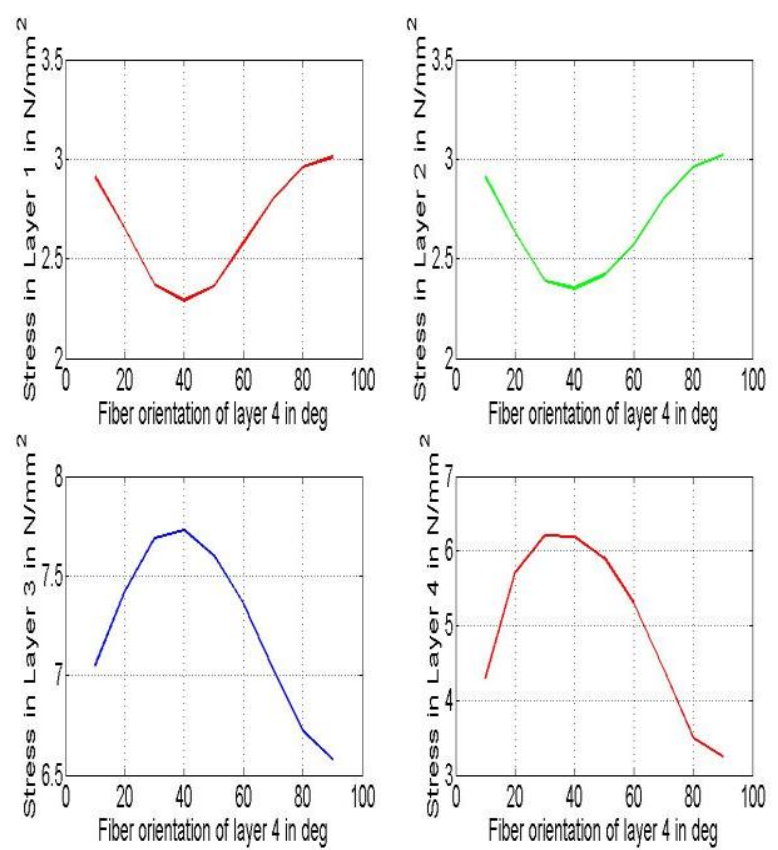

\subsection{Variation of Deflection with Fibre Angle Orientation of Different Layers}

\begin{tabular}{|l|l|l|l|l|}
\hline $\begin{array}{l}\text { Configur } \\
\text { ation }\end{array}$ & $\begin{array}{l}\text { Deflectio } \\
\text { n1 }\end{array}$ & $\begin{array}{l}\text { Deflectio } \\
\text { n2 }\end{array}$ & $\begin{array}{l}\text { Deflectio } \\
\text { n3 }\end{array}$ & $\begin{array}{l}\text { Deflectio } \\
\text { n4 }\end{array}$ \\
\hline $0 / 10 / 0 / 0$ & $2.82 \mathrm{E}-04$ & $2.82 \mathrm{E}-04$ & $2.82 \mathrm{E}-04$ & $2.82 \mathrm{E}-04$ \\
\hline $0 / 20 / 0 / 0$ & $2.71 \mathrm{E}-04$ & $2.71 \mathrm{E}-04$ & $2.71 \mathrm{E}-04$ & $2.71 \mathrm{E}-04$ \\
\hline $0 / 30 / 0 / 0$ & $2.59 \mathrm{E}-04$ & $2.59 \mathrm{E}-04$ & $2.59 \mathrm{E}-04$ & $2.59 \mathrm{E}-04$ \\
\hline $0 / 40 / 0 / 0$ & $2.54 \mathrm{E}-04$ & $2.54 \mathrm{E}-04$ & $2.54 \mathrm{E}-04$ & $2.54 \mathrm{E}-04$ \\
\hline $0 / 50 / 0 / 0$ & $2.57 \mathrm{E}-04$ & $2.57 \mathrm{E}-04$ & $2.57 \mathrm{E}-04$ & $2.57 \mathrm{E}-04$ \\
\hline $0 / 60 / 0 / 0$ & $2.65 \mathrm{E}-04$ & $2.65 \mathrm{E}-04$ & $2.65 \mathrm{E}-04$ & $2.65 \mathrm{E}-04$ \\
\hline $0 / 70 / 0 / 0$ & $2.76 \mathrm{E}-04$ & $2.76 \mathrm{E}-04$ & $2.76 \mathrm{E}-04$ & $2.76 \mathrm{E}-04$ \\
\hline $0 / 80 / 0 / 0$ & $2.84 \mathrm{E}-04$ & $2.84 \mathrm{E}-04$ & $2.84 \mathrm{E}-04$ & $2.84 \mathrm{E}-04$ \\
\hline $0 / 90 / 0 / 0$ & $2.87 \mathrm{E}-04$ & $2.87 \mathrm{E}-04$ & $2.87 \mathrm{E}-04$ & $2.87 \mathrm{E}-04$ \\
\hline
\end{tabular}

\subsubsection{Layer 1}

Variations in deflection by changing fibre angle orientation of layer 1
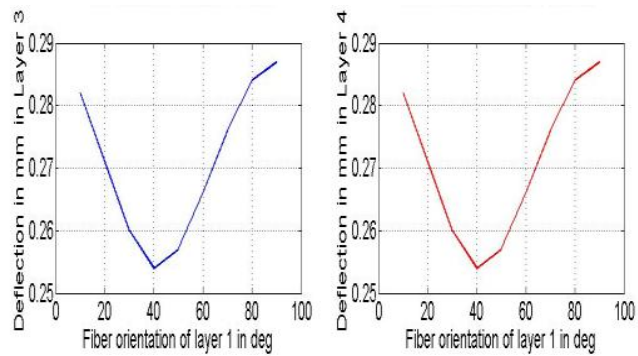

\subsubsection{Layer 2}

Figure 6.5 Variations in deflection by changing fibre angle orientation of layer 1
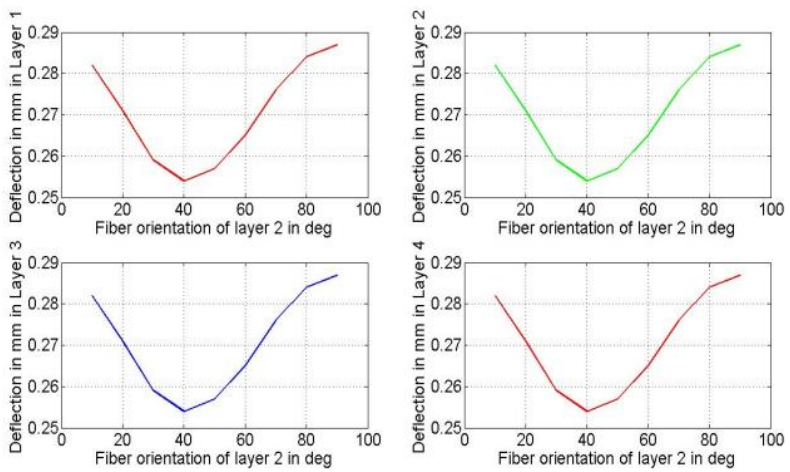

Table 7 Variations in deflection by changing fibre angle orientation of layer 2

\begin{tabular}{|l|l|l|l|l|}
\hline $\begin{array}{l}\text { Configu } \\
\text { ration }\end{array}$ & $\begin{array}{l}\text { Deflection } \\
1\end{array}$ & $\begin{array}{l}\text { Deflectio } \\
\text { n2 }\end{array}$ & $\begin{array}{l}\text { Deflection } \\
3\end{array}$ & $\begin{array}{l}\text { Deflectio } \\
\text { n4 }\end{array}$ \\
\hline $0 / 0 / 10 / 0$ & $2.60 \mathrm{E}-04$ & $2.60 \mathrm{E}-04$ & $2.60 \mathrm{E}-04$ & $2.60 \mathrm{E}-04$ \\
\hline $0 / 0 / 20 / 0$ & $2.11 \mathrm{E}-04$ & $2.11 \mathrm{E}-04$ & $2.11 \mathrm{E}-04$ & $2.11 \mathrm{E}-04$ \\
\hline $0 / 0 / 30 / 0$ & $1.85 \mathrm{E}-04$ & $1.85 \mathrm{E}-04$ & $1.85 \mathrm{E}-04$ & $1.85 \mathrm{E}-04$ \\
\hline $0 / 0 / 40 / 0$ & $1.88 \mathrm{E}-04$ & $1.88 \mathrm{E}-04$ & $1.88 \mathrm{E}-04$ & $1.88 \mathrm{E}-04$ \\
\hline $0 / 0 / 50 / 0$ & $2.09 \mathrm{E}-04$ & $2.09 \mathrm{E}-04$ & $2.09 \mathrm{E}-04$ & $2.09 \mathrm{E}-04$ \\
\hline $0 / 0 / 60 / 0$ & $2.36 \mathrm{E}-04$ & $2.36 \mathrm{E}-04$ & $2.36 \mathrm{E}-04$ & $2.36 \mathrm{E}-04$ \\
\hline $0 / 0 / 70 / 0$ & $2.62 \mathrm{E}-04$ & $2.62 \mathrm{E}-04$ & $2.62 \mathrm{E}-04$ & $2.62 \mathrm{E}-04$ \\
\hline $0 / 0 / 80 / 0$ & $2.81 \mathrm{E}-04$ & $2.81 \mathrm{E}-04$ & $2.81 \mathrm{E}-04$ & $2.81 \mathrm{E}-04$ \\
\hline $0 / 0 / 90 / 0$ & $2.87 \mathrm{E}-04$ & $2.87 \mathrm{E}-04$ & $2.87 \mathrm{E}-04$ & $2.87 \mathrm{E}-04$ \\
\hline
\end{tabular}

\subsubsection{Layer 3}

Table 8 Variations in deflection by changing fibre angle orientation of layer 3

\begin{tabular}{|l|l|l|l|l|}
\hline $\begin{array}{l}\text { Configurati } \\
\text { on }\end{array}$ & $\begin{array}{l}\text { Deflectio } \\
\text { n1 }\end{array}$ & $\begin{array}{l}\text { Deflectio } \\
\text { n2 }\end{array}$ & $\begin{array}{l}\text { Deflectio } \\
\text { n3 }\end{array}$ & $\begin{array}{l}\text { Deflectio } \\
\text { n4 }\end{array}$ \\
\hline $0 / 0 / 0 / 10$ & $2.66 \mathrm{E}-04$ & $2.66 \mathrm{E}-04$ & $2.66 \mathrm{E}-04$ & $2.66 \mathrm{E}-04$ \\
\hline $0 / 0 / 0 / 20$ & $2.25 \mathrm{E}-04$ & $2.25 \mathrm{E}-04$ & $2.25 \mathrm{E}-04$ & $2.25 \mathrm{E}-04$ \\
\hline $0 / 0 / 0 / 30$ & $1.99 \mathrm{E}-04$ & $1.99 \mathrm{E}-04$ & $1.99 \mathrm{E}-04$ & $1.99 \mathrm{E}-04$ \\
\hline $0 / 0 / 0 / 40$ & $1.99 \mathrm{E}-04$ & $1.99 \mathrm{E}-04$ & $1.99 \mathrm{E}-04$ & $1.99 \mathrm{E}-04$ \\
\hline $0 / 0 / 0 / 50$ & $2.16 \mathrm{E}-04$ & $2.16 \mathrm{E}-04$ & $2.16 \mathrm{E}-04$ & $2.16 \mathrm{E}-04$ \\
\hline $0 / 0 / 0 / 60$ & $2.40 \mathrm{E}-04$ & $2.40 \mathrm{E}-04$ & $2.40 \mathrm{E}-04$ & $2.40 \mathrm{E}-04$ \\
\hline $0 / 0 / 0 / 70$ & $2.64 \mathrm{E}-04$ & $2.64 \mathrm{E}-04$ & $2.64 \mathrm{E}-04$ & $2.64 \mathrm{E}-04$ \\
\hline $0 / 0 / 0 / 80$ & $2.81 \mathrm{E}-04$ & $2.81 \mathrm{E}-04$ & $2.81 \mathrm{E}-04$ & $2.81 \mathrm{E}-04$ \\
\hline $0 / 0 / 0 / 90$ & $2.87 \mathrm{E}-04$ & $2.87 \mathrm{E}-04$ & $2.87 \mathrm{E}-04$ & $2.87 \mathrm{E}-04$ \\
\hline
\end{tabular}



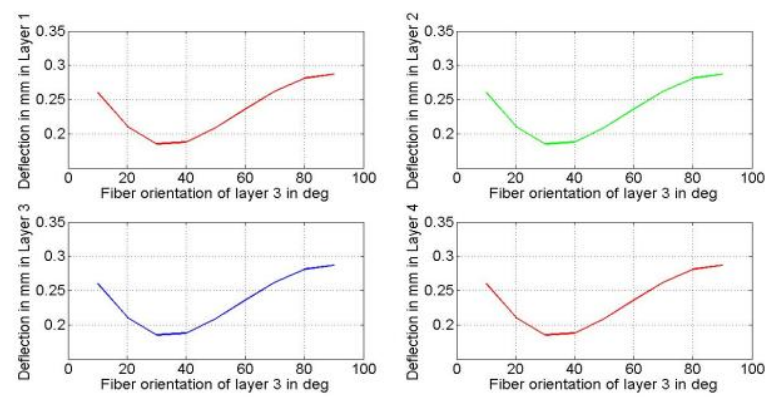

Fig 5 Variations in deflection by changing fibre angle orientation of layer 3

\subsubsection{Layer 4}

Variations in deflection by changing fibre angle orientation of layer 4

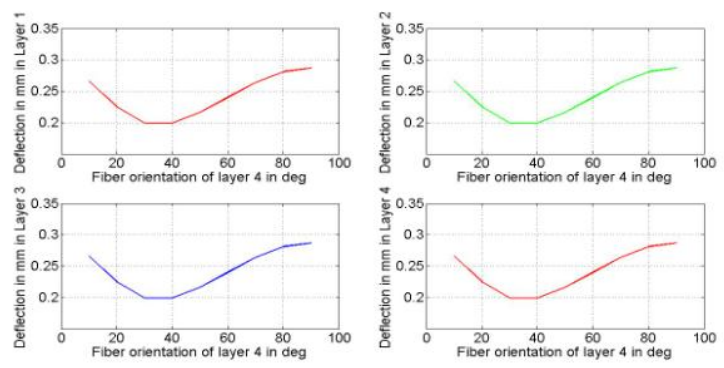

Fig 6 Variations in deflection by changing fibre angle orientation of layer 4

\subsection{Comparison of Composite Shaft with Shaft made up of Steel}

\begin{tabular}{|l|l|l|}
\hline & Steel & Composite \\
\hline Max stresses & $0.897 \mathrm{e}+07$ & $0.424 \mathrm{e}+07$ \\
\hline Deflection & $0.249 \mathrm{e}-03$ & $0.152 \mathrm{e}-04$ \\
\hline
\end{tabular}

Conventional drive shaft is made up of steel for most of the automobile, but sometimes aluminium is also used. To understand the effect of composite material in design, strength of the steel shaft is compared with that of the composite shaft. In the present analysis conventional shaft was modelled with its length as $1 \mathrm{~m}$, diameter $0.05 \mathrm{~m}$ and thickness $0.002032 \mathrm{~m}$. The same dimensions are used for the analysis of composite shaft. Comparison is carried out based on maximum deformation and maximum stresses induced in the shaft.

\section{CONCLUSIONS}

Following conclusions are drawn from the results obtained from these analyses-

1. The High Strength Carbon/Epoxy and High Modulus Carbon/Epoxy Composite drive shafts have been designed to replace the steel drive shaft of an automobile

2. The weight savings of the High strength carbon/epoxy and high modulus carbon/epoxy shafts were equal to 50 $\%$ approximately of the steel shaft

3. Optimum fibre angle orientation will play important role in composite shaft which depends on requirement of composite shaft

4. The design procedure is studied and along with finite element analysis some important parameter are obtained. The composite drive shaft made up of HM carbon / epoxy multilayered composites has been designed. The results reveal that the orientation of fibres has great influence on the static characteristics of the composite shafts and offers advantages such as
a. Lower weight
b. Higher strength
c. Progressive failure mechanism (offers warning before failure)
d. Lower power consumption

5. The present finite element analysis of the design variables provide an insight of their effects on the drive shaft's critical mechanical characteristics and fatigue resistance. A model of hybridized layers was generated incorporating carbon-epoxy. The buckling, which dominates the failure mode, have a value which not increases regularly with increasing the winding angle.

6. Regression Analysis was done to obtain relations between fibre angle orientation and parameters like stresses induced in each layer, deflection in each layer and natural frequencies of the composite shaft.

7. This relation helps in finding the above mentioned parameters at any fibre orientation; which will help to optimize the design of a composite shaft and hence will reduce the cost of manufacturing.

\section{REFERENCES}

[1] T. Rangaswamy, et al., "Optimal design and analysis of automotive composite drive shaft", 2004.

[2] M. A. Badie, et al., "Automotive composite driveshafts: investigation of the design variables effects" 2006, pp. 227-237.

[3] Y. A. Khalid, et al, "Bending fatigue behavior of hybrid aluminum/composite drive shafts", 2005.

[4] A. R. Abu Talib, et al., "Developing a hybrid, carbon/glass fiber-reinforced, epoxy composite automotive drive shaft", 2010, pp. 514-521.

[5] A. Gebresilassie, "Design and analysis of composite drive shaft for rear-wheel drive engine", Volume 3, Issue 5, May-2012.D. Jebakani, T. Paul Robert, "Particle swarm optimization for RBDO of composite drive shaft", European Journal of Scientific Research, 